\title{
Centrum, peryferie, pogranicze
}

Jan Holzer ${ }^{1}$

Link do artykułu:

http://pogranicze.uni.opole.pl/biblioteka/docs/nr1/holzer_nr1.pdf

Standard cytowania (APA):

Holzer, J. (2013). Centrum, peryferie, pogranicze. Pogranicze. Polish Borderlands

Studies, $n r$ 1, s. 72.

Moje wstępne pytanie brzmi: na ile kategoria „pogranicza” jest użyteczna w standardowej analizie politologicznej, w kontekście istnienia kategorii centrum-peryferie? Czy terminy te wykazują jakieś braki definicyjne? $\mathrm{Na}$ to pytanie odpowiedziałbym, że teoria podziału na centrum-peryferie jest wyczerpująca, tym samym kategoria pogranicza powinna pozostawać na marginesie analizy politologicznej. W końcu mojego komentarza jednak trochę relatywizuję tę opinię.

Problem teorii centrum-peryferie Immanuela Wallersteina, która powstała w ramach teorii stosunków międzynarodowych, związany jest z tym, iż centrum definiowane jest jako uprzywilejowana część konkretnego terytorium, która kontroluje i uzależnia od siebie peryferia (nawet jeśli samo centrum jest zależne od dóbr, źródłem których są peryferia). Peryferia rozumiane są jako terytoria podporządkowane władzy centrum, którego wartości i funkcje wyznaczają rozumienie wartości i funkcji peryferii.
Terminy te są ważne nie tylko dla stosunków międzynarodowych, ale i dla nauk politycznych (warto wspomnieć np. Steina Rokkana). W świecie zdominowanym przez trendy globalizacji i lokalności, państwo narodowe, jako podstawowy typ systemu politycznego znajduje się pod niemałym naciskiem procesów, których kluczowe znaczenie - w kontekście politologicznym - polega na zmianie rozumienia terminu ,granica”. Jest to kategoria podstawowa dla analizy politologicznej, bez niej sens tracą inne kategorie, takie jak system i reżim. Bez granic nie byłoby też rzecz jasna centrów i peryferii; a także pograniczy.

Ta końcowa uwaga oznacza, że kategoria „pogranicza” może być moim zdaniem kategorią perspektywiczną i ma szanse na ugruntowanie swojej pozycji w terminologii nauk politycznych. Potrzebna jest jednak jej konceptualizacja (np. jako nowych semi-peryferii, zawsze szukających możliwości do przeistoczenia się w nowe centrum, którego cech jeszcze nie posiadają). Przede wszystkim jednak najistotniejsze dziś, nie po raz pierwszy, jest pytanie o granice.

\footnotetext{
$\overline{1}$ Prof. dr hab. Jan Holzer: pracownik Zakładu Teorii Polityki i Metodologii Politologii Uniwersytetu Marii
} Curie-Skłodowskiej w Lublinie i Instytutu Nauk Politycznych Uniwersytetu Masaryka w Brnie. 